DOI 10.18551/rjoas.2020-04.13

\title{
ANALYSIS OF HOSPITALIZATION SERVICE QUALITY ON THE INPATIENTS OF MUTIARA BUNDA MALANG MATERNITY HOSPITAL USING SERVQUAL AND KANO MODELS
}

\author{
Kristina, Fathorrahman, Karnawati Tin Agustina \\ Master of Management Program, Institut Teknologi and Bisnis Asia Malang, Indonesia \\ ${ }^{*}$ E-mail: faturrahman.asia.74@gmail.com
}

\begin{abstract}
Good service quality could be known by comparing patients' perceptions of services that are actually received with their expected or desired services towards company service attributes. This study aimed at measuring the gaps and differences between patients' expectations and perceptions about the dimensions of hospitalization service quality, also developing strategies to improve the service quality in Maternity Hospital of Mutiara Bunda Malang. Quantitative approach was applied to all inpatients, in total of 100 respondents who were selected by purposive sampling technique. The data were obtained under observation, interview, and questionnaire methods which were analyzed using quantitative descriptive analysis by Servqual and Kano models. The results showed that the Servqual measurement of all hospitalization service attributes had a negative gap score, which meant that the quality of service in Mutiara Bunda Malang Maternity Hospital has not met patients' expectations, with Kano method in order to bridge the gap. Strategies for improving the quality of inpatient services from 24 service attributes were divided into two categories of Kano, namely must be (this category is the basic needs that must be met) and one dimensional (if this category is met, then consumer's satisfaction is increased). The Must be category must be prioritized, after that, the hospital endeavor to improve the quality of service in One Dimensional category.
\end{abstract}

\section{KEY WORDS}

Service Quality, Servqual Method, Kano Method.

Health services are very important for the survival of every human being. Thus, the government always emphasizes to establish public health services that are easily accessed. However, the service quality proclaimed by the government is sometimes not as expected by patients. The health service problems that often occur in outpatients and inpatients in hospitals are the quality of services that are not optimal, communication between health workers and patients, until the hospital environment that is not comfortable. In 2019, there were several service quality problems, such as happened in Asy Syfa Hospital Tulangbawang Regency July 2019, due to the negligence of health worker teams during surgery on mothers who gave birth by cesarean section. It was alleged that there was gauze in the stomach of the mother for 3 months, and discovered after taking medical treatment (Gunawan, 2019).

Patient's satisfaction become the benchmark of service quality in a hospital. A good service quality could be known by comparing patients' perceptions of services that are actually received to their expected or desired services towards company service attributes. Servqual is one of measurement methods used to measure service quality. Servqual was developed based on the comparison of two main factors, those are consumer's perception toward perceived service and expected service. If the reality is better than expected, then the service can be said as qualified, and vice versa. Service quality measures how far the different perceptions and expectations of consumers for the services they receive in Servqual. There are five dimensions measured, namely tangible, reliability, responsiveness, empathy, and assurance, in which these five attributes are mapped into several scoring attributes (Parasuraman, et al., in Sunyoto and Fathonah, 2015). 
Servqual method only discovers the gaps from perceptions and expectations of the patients, but there were no plans of improvement in the future. By using Kano method, the company will know what actions will match the patients' needs. Kano model is a model aimed at categorizing product and service attributes based on how good the product or service in satisfying consumer's needs (Wijaya, 2018).

The measurement of service quality level is significant, especially to improve the service quality and to get loyal consumers. Loyal consumer will bring benefits for the company. A bad and disappointing service is a failure for a service company. In health organization, to fulfill consumer's needs and to keep the consumer become the main goal of the company (Setyaningsih, 2013). The result of Rumintjap and Wondebori's research (2017) stated that in service quality dimension found that there was a gap between expectation and perception, thus affected patients' satisfaction. It is supported by Wulandari's research result (2018), mentioned that effective communication between health workers and patients affected service quality in a hospital.

Mutiara Bunda Maternity Hospital is one of the hospitals that mostly care for inpatients of mothers giving birth, women with problems in their wombs, and children. Mutiara Bunda Malang Maternity Hospital has a very flexible inpatient procedure since they do not require patients to make advance payment. Inpatient services in Mutiara Bunda Malang Maternity Hospital are always evaluated through questionnaire distributed into inpatients and outpatients, then it will be recapitulated annually to evaluate health workers' performance given by the patients whether it has met the standards or not. In 2019, the result of the questionnaire mentioned that the management stated $85 \%$ inpatient services in Mutiara Bunda Malang Maternity Hospital has met the patients' expectations. Other than that, $15 \%$ of the questionnaires resulted on the statement that the service given has not met the expectations of the patients when they come to get health service at Mutiara Bunda Malang Maternity Hospital.

\section{METHODS OF RESEARCH}

This study applied descriptive qualitative research approach. In this study, the population taken was all inpatients at Mutiara Bunda Malang Maternity Hospital. The sampling technique used was purposive sampling. The sample criteria in this study are female patients over 17 years of age (if less than 17 years old but married will still be the respondents), 17 is the age limit between children and adult according to WHO, women who give birth or are hospitalized with uterus cases (for example: surgical removal of the tumor in the womb, hyperemesis, etc.) and female patients who are hospitalized for $\geq 2$ days. The sample size of the study is 100 respondents, based on Cooper and Emory (1997), that for a population that the number is not exactly identified, then the sample is directly determined by 100 respondents. This assumption indicated that the absolute size (number) of the sample is more important than the size of its proportion to the population. The sample size of 100 is sufficient to meet the requirement of representative sample (Cooper and Emory, 1997). The data collection methods were using observation, interview, documentation, and questionnaire. This research used excel and IBM SPSS statistics 23 software devices in analyzing the data.

\section{RESULTS AND DISCUSSION}

From table 1, it can be concluded that the respondents in this study were mostly in senior/vocational high school level as $44 \%$, categorized into the age of 29-39 by $48 \%$, had a private sector job as 38\%, and 2-days inpatient stayed at Mutiara Bunda Malang Maternity Hospital as $56 \%$.

Parasuraman, Zethaml, and Berry (1985), stated that one of the factors that determine consumer satisfaction is the quality of service consists of five dimensions of service gap, in which there is a mismatch between perceived service and expected service. Servqual is a simple scale selection but has high accuracy level that company management can use to 
comprehend how consumers' (patients) perceptions and consumers' expectations of the services provided. Measurement of inpatient service quality in the Servqual method was based on a multi-item scale designed to measure patient expectations and perceptions, as well as its gaps, based on five main dimensions of service quality (Tangibles, Reliability, Responsiveness, Assurance, and Empathy). Those five main dimensions were elaborated into each 24 indicators in details to measure the respondents' (patients) level of expectations and level of perceptions, which were arranged into statements according to Likert-scale.

Table 1 - Demographic Data of Respondents

\begin{tabular}{|c|c|c|c|c|c|c|c|}
\hline \multicolumn{2}{|c|}{ Education } & \multicolumn{2}{c|}{ Age } & \multicolumn{2}{c|}{ Occupation } & \multicolumn{2}{c|}{ Inpatient Duration } \\
\hline Category & $\%$ & Category & $\%$ & Category & Percentage (\%) & Category & $\%$ \\
\hline ELEMENTARY & 4 & $\leq 17$ y.o. & 3 & Private sector & 38 & 2 days & 56 \\
\hline JUNIOR HIGH & 8 & $18-28$ y.o. & 41 & Civil servant & 12 & $>2$ days & 44 \\
\hline SENIOR HIGH & 44 & $29-39$ y.o. & 48 & Entrepreneur & 23 & & \\
\hline DIPLOMA & 20 & $40-50$ y.o. & 6 & Not working & 27 & & \\
\hline BACHELOR & 24 & $\geq 50$ y.o. & 2 & & & & \\
\hline
\end{tabular}

Source: Data Processed, 2020.

Servqual measurement was used to calculate the gaps between consumer's perceptions toward service minus expectation score or consumer's expectation. The score could be defined from this formula: GS (Gap score) = P (perceptions) - E (expectations). Previously, there were two steps of calculations, namely:

1. Total score of each service attributes for the dimensions of respondent's expectation and perception, as follows.

Expectation score, using the following formula:

$$
\text { Total Score }=(E 1 \times 1)+(E 2 \times 2)+(E 3 \times 3)+(E 4 \times 4)+(E 5 \times 5)
$$

In which, E1: number of respondents with 'not a must' answer; E2: number of respondents with 'less needed' answer; E3: number of respondents with 'enough' answer; E4: number of respondents with 'it's a must' answer; E5: number of respondents with 'extremely need it' answer.

Perception score, using the following formula:

$$
\text { Total Score }=(\mathrm{P} 1 \times 1)+(\mathrm{P} 2 \times 2)+(\mathrm{P} 3 \times 3)+(\mathrm{P} 4 \times 4)+(\mathrm{P} 5 \times 5)
$$

In which, P1: number of respondents with 'extremely bad' answer; P2: number of respondents with 'poor' answer; P3: number of respondents with 'enough' answer; P4: number of respondents with 'good' answer; P5: number of respondents with 'excellent' answer.

2. Divide the total score with the number of respondents, the formula:

$$
\text { Expectation } / \text { Perception Score }=\text { Total score } / \text { Number of respondents }
$$

Servqual measurement results on the dimensions of inpatient service quality in Mutiara Bunda Malang Maternity Hospital showed that there is a gap between the expectations and perceptions of respondents, as seen in Table 2.

All five dimensions of inpatient service quality at Mutiara Bunda Malang Maternity Hospital had negative gap score, meaning that the inpatients service provided was under the expectation. The highest average gap score was on the attribute of Responsiveness dimension as -0.90 . The result of this study was differ from previous research conducted by Kalaja, et al (2016), mentioned that the gaps of patients' expectations and perceptions showed positive score from the five service dimensions, Tangibles, Reliability, Responsiveness, Assurance, and Empathy, meaning that the average inpatients at Durres Hospital satisfied with the provided service. However, this study seconds Rezaei, et al research (2016), stating that there were negative gaps on the five dimensions, Tangibles, 
Reliability, Responsiveness, Assurance, and Empathy. The patients voted response as the most important dimension in the health service quality. The average gap score of the five dimensions of inpatients service at Mutiara Bunda Malang Maternity Hospital from the highest to the lowest score can be seen in Figure 1.

Table 2 - Gap Scores of Five Service Dimensions

\begin{tabular}{|c|c|c|c|c|}
\hline \multirow{2}{*}{ No } & \multirow{2}{*}{ Service Attribute Dimensions } & Perception score & Expectation score & Gap Score \\
\hline & & $\mathrm{P}$ & E & $G S=P-E$ \\
\hline \multicolumn{5}{|c|}{ Tangibles } \\
\hline 1 & Adequate hospital facilities & 3.46 & 4.17 & -0.71 \\
\hline 2 & Modern medical equipment & 3.63 & 3.96 & -0.33 \\
\hline 3 & Clean and neat rooms & 3.54 & 4.66 & -1.12 \\
\hline 4 & Clean and neat employee appearance & 3.51 & 4.01 & -0.5 \\
\hline \multicolumn{5}{|c|}{ Reliability } \\
\hline 5 & Service provided as the agreement & 3.68 & 4.28 & -0.6 \\
\hline 6 & Regular and on-time patients' checking & 3.68 & 4.51 & -0.83 \\
\hline 7 & Drugs administration based on the diagnosis & 3.72 & 4.77 & -1.05 \\
\hline 8 & Good and clear explanation of the diagnosis & 3.68 & 4.52 & -0.84 \\
\hline \multicolumn{5}{|c|}{ Responsiveness } \\
\hline 9 & Handling patients responsively & 3.67 & 4.45 & -0.78 \\
\hline 10 & Inform the patient about the actions will be taken & 3.68 & 4.77 & -1.09 \\
\hline 11 & Come immediately when it's urgent & 3.91 & 4.77 & -0.86 \\
\hline 12 & Officers are always responsive in responding to requests & 3.61 & 4.48 & -0.87 \\
\hline \multicolumn{5}{|c|}{ Assurance } \\
\hline 13 & Be polite when treating the patients & 3.67 & 4.41 & -0.74 \\
\hline 14 & No doubt in taking action & 3.51 & 4.51 & -1 \\
\hline 15 & Be cautious in taking action & 3.42 & 4.41 & -0.99 \\
\hline 16 & Inform each treatment results to the patients & 3.62 & 4.61 & -0.99 \\
\hline 17 & Evaluating the action & 3.54 & 4.51 & -0.97 \\
\hline 18 & Answer the questions from patients well & 3.51 & 4.51 & -1 \\
\hline \multicolumn{5}{|c|}{ Empathy } \\
\hline 19 & Call the names before make any treatments & 3.83 & 4.47 & -0.64 \\
\hline 20 & Ask the condition periodically & 3.67 & 4.37 & -0.7 \\
\hline 21 & Ask the patients' problems & 3.64 & 4.28 & -0.64 \\
\hline 22 & Providing times to listen patients' complaints & 3.46 & 4.27 & -0.81 \\
\hline 23 & Be patient, unhurried, and gentle in doing the treatment & 3.51 & 4.27 & -0.76 \\
\hline 24 & Seemed to understand how the patient feels & 3.54 & 4.17 & -0.63 \\
\hline
\end{tabular}

Source: Data Processed, 2020.

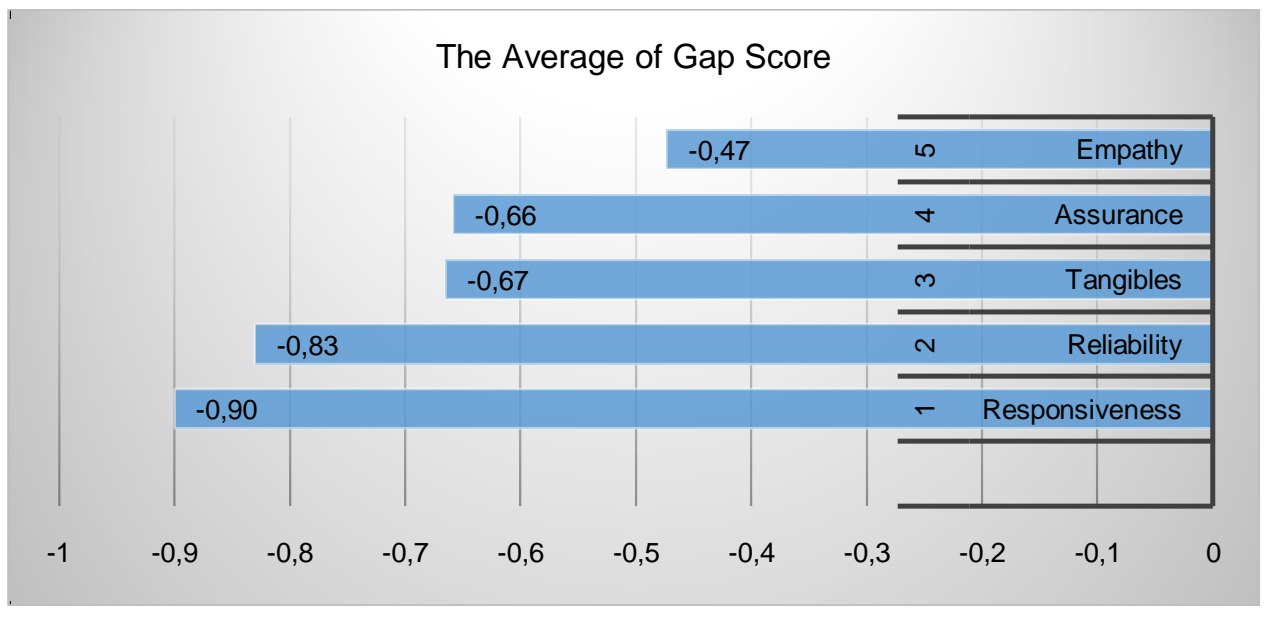

Figure 1 - The Average Gap score of Five Service Dimensions

Noriaki Kano in 1984 developed a diagram used to classify attributes of products or services according to how the products or service could satisfy the consumers. In the Kano method, the most important process was to identify the classification of each service attributes. Kano model distinguished three types of products needed which could influence the consumers' satisfaction, namely Must-be requirements (this category is basic. If this category cannot be fulfilled, then the consumers will be extremely dissatisfied), One- 
dimensional requirements (in this category, consumer satisfaction is proportional to the performance attribute), and Attractive requirements (the fulfillment of this category will increase the consumer's satisfaction into the highest, but if it is not fulfill, there is no cause on decreasing satisfaction level) (Wijaya, 2018).

By using Servqual and Kano methods, it can cover the weakness of each methods compared to use the method separately. Modifying the Servqual attributes became the functional question (positive) and dysfunctional (negative). Likert-scale was also used in Kano method since the options could be answered by the respondents. The results of respondents' answers on the functional and dysfunctional questions were figured the crossings of the answers on each questions. The Determination Table can be seen in the Table 3.

Table 3 - Evaluation of Kano Model

\begin{tabular}{|c|c|c|c|c|c|c|}
\hline \multirow{2}{*}{\multicolumn{2}{|c|}{ Inpatients needs }} & \multicolumn{5}{|c|}{ Dysfunctional } \\
\hline & & 1 & 2 & 3 & 4 & 5 \\
\hline & & Like & Expecting & Neutral & Tolerance & Dislike \\
\hline \multirow{5}{*}{ 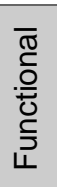 } & 1. Like & Q & A & A & A & $\mathrm{O}$ \\
\hline & 2. Expecting & $\mathrm{R}$ & I & I & I & $\mathrm{M}$ \\
\hline & 3. Neutral & $\mathrm{R}$ & I & I & I & $M$ \\
\hline & 4. Tolerance & $\mathrm{R}$ & I & 1 & 1 & $\mathrm{M}$ \\
\hline & 5. Dislike & $\mathrm{R}$ & $\mathrm{R}$ & $\mathrm{R}$ & $\mathrm{R}$ & Q \\
\hline
\end{tabular}

Note: If the question no.1 for functional question was answered by "Like", and the question no. 1 in dysfunctional question was answered by "Dislike", then based on the crossing in the Table of Kano Model Evaluation, the attribute for question number one was classified into One dimensional, keep in mind that for 1 attribute question, the total number of Kano Model should as the same number as the total respondents taken previously. The categories of Kano Models are: $Q=$ Questionable, $R=$ Reverse, $A=$ Attractive, $I=I n d i f f e r e n t, O=O n e$ Dimensional, $M=$ Must Be.

In determining the category (classification) of Kano Model for each attributes, Blauth Formula was used (Walden, 1993 in Wijaya 2018) as follows:

- If (one dimensional + attractive + must be) > (indifferent + reverse + questionable), then the grade was obtained from the most maximum of (one dimensional, attractive, must be);

- If (one dimension + attractive + must be) < (indifferent + reverse + questionable), then the grade was obtained from the most maximum of (indifferent, reverse, questionable);

- If the total score (one dimensional + attractive + must be $)=($ indifferent + reverse + questionable), then the grade was obtained from the most maximum of all Kano categories, those are one dimensional, attractive, must be, indifferent, reverse, questionable.

The classification result of Kano model for each service attributes using Blauth Formula can be seen in the Table 4.

Table 4 - Classification Result of Kano Model

\begin{tabular}{|c|c|c|c|c|c|c|c|c|c|c|c|}
\hline \multirow{2}{*}{ No } & \multirow{2}{*}{ Attribute } & \multicolumn{6}{|c|}{ Classification } & \multirow{2}{*}{ Total } & \multirow{2}{*}{$(\mathrm{O}+\mathrm{A}+\mathrm{M})$} & \multirow{2}{*}{$(I+R+Q)$} & \multirow{2}{*}{ Category } \\
\hline & & $\mathrm{A}$ & $\mathrm{O}$ & $\mathrm{M}$ & $\mathrm{I}$ & $\mathrm{R}$ & Q & & & & \\
\hline 1 & Adequate hospital facilities & 21 & 28 & 13 & 38 & 0 & 0 & 100 & 62 & 38 & $\mathrm{O}$ \\
\hline 2 & Modern medical equipment & 20 & 28 & 20 & 32 & 0 & 0 & 100 & 68 & 32 & $\mathrm{O}$ \\
\hline 3 & Clean and tidy rooms & 12 & 35 & 30 & 22 & 0 & 1 & 100 & 77 & 23 & $\mathrm{O}$ \\
\hline 4 & Clean and neat staffs' appearance & 17 & 28 & 21 & 27 & 0 & 7 & 100 & 66 & 34 & $\mathrm{O}$ \\
\hline 5 & Service provided as the agreement & 17 & 29 & 21 & 27 & 0 & 6 & 100 & 67 & 33 & $\mathrm{O}$ \\
\hline 6 & Regular and on-time patients' checking & 17 & 35 & 21 & 27 & 0 & 0 & 100 & 73 & 27 & $\mathrm{O}$ \\
\hline 7 & $\begin{array}{l}\text { Drugs administration based on the } \\
\text { diagnosis }\end{array}$ & 10 & 51 & 27 & 12 & 0 & 0 & 100 & 88 & 12 & $\mathrm{O}$ \\
\hline 8 & $\begin{array}{l}\text { Good and clear explanation of the } \\
\text { diagnosis }\end{array}$ & 10 & 51 & 27 & 12 & 0 & 0 & 100 & 88 & 12 & $\mathrm{O}$ \\
\hline 9 & Handling patients responsively & 11 & 36 & 27 & 26 & 0 & 0 & 100 & 74 & 26 & $\mathrm{O}$ \\
\hline 10 & $\begin{array}{l}\text { Inform the patient about the actions will } \\
\text { be taken }\end{array}$ & 9 & 39 & 29 & 23 & 0 & 0 & 100 & 77 & 23 & $\mathrm{O}$ \\
\hline
\end{tabular}




\begin{tabular}{|c|c|c|c|c|c|c|c|c|c|c|c|}
\hline 11 & Come immediately when it's urgent & 14 & 46 & 22 & 17 & 0 & 1 & 100 & 82 & 18 & $\mathrm{O}$ \\
\hline 12 & $\begin{array}{l}\text { Officers are always responsive in } \\
\text { responding to requests }\end{array}$ & 11 & 45 & 23 & 20 & 0 & 1 & 100 & 79 & 21 & $\mathrm{O}$ \\
\hline 13 & Be polite when treating the patients & 14 & 45 & 23 & 17 & 0 & 1 & 100 & 82 & 18 & $\mathrm{O}$ \\
\hline 14 & No doubt in taking action & 15 & 37 & 24 & 23 & 0 & 1 & 100 & 76 & 24 & $\mathrm{O}$ \\
\hline 15 & Be cautious in taking action & 11 & 41 & 30 & 17 & 0 & 1 & 100 & 82 & 18 & $\mathrm{O}$ \\
\hline 16 & $\begin{array}{l}\text { Inform each treatment results to the } \\
\text { patients }\end{array}$ & 12 & 36 & 25 & 26 & 0 & 1 & 100 & 73 & 27 & $\mathrm{O}$ \\
\hline 17 & Evaluating the action & 7 & 44 & 34 & 14 & 0 & 1 & 100 & 85 & 15 & $\mathrm{O}$ \\
\hline 18 & Answer the questions from patients well & 7 & 45 & 33 & 14 & 0 & 1 & 100 & 85 & 15 & $\mathrm{O}$ \\
\hline 19 & $\begin{array}{l}\text { Call the names before make any } \\
\text { treatments }\end{array}$ & 16 & 41 & 21 & 21 & 0 & 1 & 100 & 78 & 22 & 0 \\
\hline 20 & Ask the condition periodically & 12 & 30 & 31 & 26 & 0 & 1 & 100 & 73 & 27 & $\mathrm{M}$ \\
\hline 21 & Ask the patients' problems & 15 & 26 & 30 & 28 & 0 & 1 & 100 & 71 & 29 & $\mathrm{M}$ \\
\hline 22 & $\begin{array}{l}\begin{array}{l}\text { Providing times to listen patients' } \\
\text { complaints }\end{array} \\
\end{array}$ & 10 & 19 & 29 & 41 & 0 & 1 & 100 & 58 & 42 & $M$ \\
\hline 23 & $\begin{array}{l}\text { Be patient, unhurried, and gentle in } \\
\text { doing the treatment }\end{array}$ & 4 & 28 & 42 & 25 & 0 & 1 & 100 & 74 & 26 & $\mathrm{M}$ \\
\hline 24 & $\begin{array}{l}\text { Seemed to understand how the patient } \\
\text { feels }\end{array}$ & 14 & 20 & 33 & 32 & 0 & 1 & 100 & 67 & 33 & M \\
\hline
\end{tabular}

Source: Data Processed, 2020.

Note: If the question no.1 for functional question was answered by "Like", and the question no. 1 in dysfunctional question was answered by "Dislike", then based on the crossing in the Table of Kano Model Evaluation, the attribute for question number one was classified into One dimensional, keep in mind that for 1 attribute question, the total number of Kano Model should as the same number as the total respondents taken previously. The categories of Kano Models are: $Q=$ Questionable, $R=$ Reverse, $A=$ Attractive, $I=$ Indifferent, $O=O n e$ Dimensional, $M=$ Must Be. And each attributes were classified using Blauth Formula.

From Table 3 can be seen that attributes 1 to 19 were categorized into one dimensional (if this category was fulfilled, then the consumer satisfaction was increased) and attribute 20 to 24 were categorized into must be (this category was the basic needs which should be fulfilled by the hospital, if it is not fulfilled, then it directly affects respondents' satisfaction into insufficient).

From all attributes of inpatient service quality as the variables in this research, namely Tangibles, Reliability, Responsiveness, Assurance, and Empathy, which been measured using Servqual showed that the lowest average gap was on Empathy dimension. However, based on Kano method measurement, empathy dimension was included into 'must be' category (the category of respondents' basic needs, if it is not fulfilled then the respondents were absolutely dissatisfied); except the point of calling the patient's name before giving treatment, was included into one dimensional category (if this category fulfilled, then the respondents' satisfaction increased). Service quality from empathy dimension at Mutiara Bunda Malang Maternity Hospital mostly respondents' expectations were fulfilled by all hospital staffs in providing inpatient service. Thus, it shaped the respondents' scoring that all service attributes in empathy dimension was the basic needs of inpatient service at Mutiara Bunda Malang Maternity Hospital. If the respondents' basic needs were not fulfilled then it will caused loss to the hospital. Supriyanto and Ernawaty (2010) stated that the hospital management aimed at producing service products and health service that truly touch the patients' needs and expectations from various aspects, regarding the quality of medical and non-medical, types of services, service procedures, prices, and information needed.

The management of Mutiara Bunda Malang Maternity Hospital conducted hospital service evaluation by giving the responsibility to public relations and marketing division to distribute the questionnaires to the inpatients and outpatients. The result of the questionnaire was asked when the patients would leave the hospital. Each year, the result of the questionnaires which have been collected in a year would be announced and all hospital staffs who have good performance would get gifts in form of goods. This effort is done to improve hospital staffs' performances so that the expectations of patients at Mutiara Bunda Malang Maternity Hospital were fulfilled.

According to the measurement result of Kano method to improve service quality at Mutiara Bunda Malang Maternity Hospital by increasing and fixing service attributes which were included in one dimensional category, those are adequate hospital facilities, modern 
medical equipment, clean and tidy room, clean and tidy employee appearance, services provided based on the agreement, periodic and timely examination of patients, administration of drugs according to diagnosis, good and clear explanation of diagnosis, quick in handling patients, informing the patient what treatments will be taken, come immediately when the situation is urgent, officers are always responsive in responding to requests, be polite when giving treatment to the patients, no doubt in taking action, be careful in taking action, inform the results of the examination to the patients, evaluate the action, answer the patient's questions well and call the name before taking action. If all of these attributes are met, then the patient's expectations will automatically be fulfilled. Good service quality is not seen from the perception of service providers, but from the perception of patients, because patient satisfaction can be achieved only from patient assessment (Hadijah, 2016).

\section{CONCLUSION}

The result of Servqual Measurement showed the position of Mutiara Bunda Malang Maternity Hospital in providing hospitalization service that there were negative gap score between expectations and perceptions of patients' in all service dimensions, which is meant that all attributes of inpatient service were under the patients' expectations.

Strategy development to improve inpatient service quality at Mutiara Bunda Malang Maternity Hospital by using Kano Method, toward 24 service attributes in this study which were divided into two categories, namely must be ( 5 service attributes) and one dimensional (19 service attributes).

\section{REFERENCES}

1. Cooper, Donald R and C. William Emory. 1997. Metode Penelitian Bisnis, Jilid 1. Fifth Edition, Erlangga, Jakarta.

2. Gunawan, H. 2019. Kain Kasa Busuk di Dalam Perut Psien, Polisi Akan Gelar Perkara Dygaan Malpraktik RS di Tubaba, Tribunnews.com.

3. Hadijah. 2016. Analisis Kualitas Pelayanan Rawat Inap Di Rumah Sakit Umum Daerah Undata Palu Provinsi Sulawesi Tengah, e-Jurnal Katalogis, Vol. 4, No. 7, Hal. 118-129.

4. Kalaja, R; Redi Myshketa and Francesco Scalera. 2016. Service Quality Assessment in Health Care Sector: The Case Ofof Durres Public Hospital, Procedia Social and Behavioral Sciences, 235, p. 557-565.

5. Parasuraman, A., Zethaml, Valerie. A. and Berry, L. Leonard. 1985. A Conseptual model of service quality and its implication for future research, Jurnal Marketing, Vol. 49, No. 4, pp. 45-50.

6. Rezaei, S, et al. 2016. Measurement of Quality of Educational Hospital Services by the SERVQUAL Model: The Iranian Patients' Perspective, Electronic Physician (ISSN: 20085842), Vol. 8 (3), p. 2101-2106.

7. Rumintjap, A. F and Harimukti Wandebori. 2017. Developing Healthcare Service Quality Model Using Serperf Scale: An Application to the inpatient Department at a Private Hospital in Bogor, Journal of Business and management, Vol. 6, No. 1, p. 56-65.

8. Setyaningsih, Ira. 2013. Analisis Kualitas Pelayanan Rumah Sakit Terhadap Pasien Menggunakan Pendekatan Lean Servperf (Lean Service and Service Performance) Studi Kasus Rumah Sakit X. Spektrum Industri, Vol. 11, No. 2, Hal 117-242.

9. Sunyoto, D., Susanti, F.E. 2015. Manajemen Pemasaran Jasa, CAPS (Centre for Academics Publishing Service), Yogyakarta.

10. Supriyanto, S. 2010. Pemasaran Industri Jasa Kesehatan, CV Andi Offset, Yogyakarta.

11. Wijaya, Toni. 2018. Manajemen Kualitas Jasa: Desain Servqual, QFD, and Kano, Edisi Kedua, PT Indeks, Jakarta.

12. Wulandari, Ida. 2018. Strategi Peningkatan Kualitas Pelayanan Rumah Sakit Berdasarkan Indikator Mutu Keselamatan Pasien: Studi Pada Rumah Sakit Umum (RSU) Hidayah Boyolali, Universitas Muhammadiyah Surakarta. 